\title{
Aplikasi Teknologi Komunikasi Wireless Berbasis Zigbee Pada Sistem Kontrol Dan Monitoring Ruangan Kelas
}

\author{
Hasta, Rulliyanto \\ Program Studi Teknik Elektro, Fakultas Teknik dan Sains, Universitas Nasional \\ Korespondensi : rulliyanto@yahoo.com
}

\begin{abstract}
ABSTRAK. Merancang aplikasi teknologi komunikasi wireless berbasis zigbee pada sistem kontrol dan monitoring ruangan kelas. Dapat memanfaatkan fungsi dari jaringan kabel wireless sebagai media untuk mengontrol peralatan listrik jarak jauh. Idenya muncul setelah melihat pemanfaatan masalah ini terjadi dalam mengendalikan peralatan listrik dengan manual. Sistem kontrol tidak efektif dan efisien, karena masih memerlukan tenaga manusia untuk mengelola dan mengontrol peralatan listrik di setiap kelas. Desain menggunakan satu makets imulasi bangunan dibagi bagian terpasangl ampu pijar, kipas dan driver motor dalam ruangan dan terhubung kerelay yang terhubung dengan arus listrik kemudian dikendalikan dengan mikrokontroler Arduino UNO R3 dan komunikasi antara kedua bagian tersebut menggunakan ZigBee.
\end{abstract}

Kata kunci: wireless, arduino, zigBee

\begin{abstract}
Design the application of wireless communications technology at the ZigBee-based control and monitoring system for the classroom. Can take advantage of the functions of a wired wireless network as a medium for controlling electrical appliances remotely. The idea came after seeing the utilization of these problems occur in electrical equipment with manual control. The control system is in effective and in efficient, because they still require manpower to manage and control electrical equipment in each class. The design uses a mock simulation of a building divided parts mounted incandescent lamp, fan and motor drivers in the room and connected to a relay that is connected to an electric current is then controlled by the microcontroller Arduino UNO R3 and communication between the two parties using ZigBee.
\end{abstract}

Keywords: wireless, arduino, zigBee

\section{PENDAHULUAN}

Perkembangan teknologi dan gaya hidup menunjukkan semakin pentingnya kepraktisan dan efisiensi menyebabkan kebutuhan untuk mengontrol berbagai beban listrik tidak hanya dilakukan dengan mengharuskan dekatp erangkat listrik dan tekan tombol on/off tetapi juga dapat dilakukan dari jarak jauh (remote control). Jadi dirancanglah sistem kontrol listrik untuk mengendalikan peralatan listrik di ruangan kelas dengan jarak jauh. Hal ini dikarenakan pengendalian peralatan listrik di ruangan kelas memerlukan suatu sistem pengontrol yang praktis dan efisien yang dapat mempermudah pekerjaan Staf. Sistem pengumpulan data yang dirancang berfungsi untuk membaca data dari berbagai modul sesuai dengan fungsinya masingmasing. Untuk mengumpulkan data tersebut sistem menggunakan mode komunikasi serial. Sistem komunikasi yang dirancang menggunakan prinsip master-slave. Master menerima perintah yang dikirimoleh PC, kemudian master akan menerjemahkan perintah tersebut untuk diteruskan kepada slave. Untuk mengatur komunikasi data antara master dan slave dibutuhkan suatu protokol komunikasi yang khusus, sehingga perancangan protokol komunikasi menjadi salah satu perancangan dan realisasi yang dilakukan.

\section{PARAMETER EKSPERIMEN}

\section{Arduino}

Arduino merupakan sistem mikrokontroller yang relatif mudah dan cepat dalam membuat aplikasi elektronika maupun robotika. Arduino terdiri dari perangkat elektronika atau papan 
rangkaian elektronika open source yang di dalamnya terdapat komponen utama yaitu sebuah chip mikrokontroler dengan jenis AVR dari perusahaan atmel. Arduino saat ini telah menggunakan seri chip mega AVR, khusus Atmega8, Atmega168, Atmega328, Atmega1280, Atmega2560. Kebanyakan papan arduino memiliki regulator linear 5 volt $16 \mathrm{MHz}$ osilator kristal.

\section{Komunikasi Data Arduino}

Arduino UNO memiliki sejumlah fasilitas untuk berkomunikasi dengan komputer, Arduino lain, atau mikrokontroler lain. ATmega328 ini menyediakan UART TTL (5V) komunikasi serial, yang tersedia pada pin digital 0 (RX) dan 1 (TX). Sebuah ATmega16U2 pada saluran board ini komunikasi serial melalui USB dan muncul sebagai com port virtual untuk perangkat lunak pada komputer. Firmware Arduino menggunakan USB driver standar COM, dan tidak ada driver eksternal yang dibutuhkan. RX dan TX LED di board akan berkedip ketika data sedang dikirim melalui chip USB-to-serial dan koneksi USB ke komputer. ATmega328 ini juga mendukung komunikasi I2C (TWI) dan SPI. Fungsi ini digunakan untuk melakukan komunikasi inteface pada sistem.

\section{Programming}

Arduino UNO dapat diprogram dengan perangkat lunak Arduino. Pilih Arduino Uno dari Tool lalu sesuaikan dengan mikrokontroler yang digunakan. Para ATmega328 pada Arduino Uno memiliki bootloader yang memungkinkan Anda untuk meng-upload program baru untuk itu tanpa menggunakan programmer hardware eksternal. Ini berkomunikasi menggunakan protokol dari bahasa C. Sistem dapat menggunakan perangkat lunak FLIP Atmel (windows) atau programmer DFU (Mac OS X dan Linux) untuk memuat firmware baru. Atau Anda dapat menggunakan header ISP dengan programmer eksternal.

\section{ZigBee}

ZigBee adalah protokol jaringan nirkabel yang ditargetkan untuk otomasi dan aplikasi remote control dengan teknologi data rate rendah, konsumsi daya rendah, dan murah. ZigBee diharapkan dapat memperkecil biaya dan menjadi konektivitas berdaya rendah untuk peralatan yang memerlukan baterai untuk hidup selama beberapa bulan sampai beberapa tahun, tetapi tidak memerlukan kecepatan transfer data tinggi seperti Bluetooth. Selain itu, ZigBee dapat diimplementasikan dalam jaringan mesh yang lebih luas dari pada yang mungkin dijangkau dengan Bluetooth. Perangkat nirkabel ZigBee diharapkan dapat digunakan untuk mengirimkan data sejauh 10-75 meter, tergantung pada lingkungan RF dan output konsumsi daya yang diperlukan untuk diberikan aplikasi. IEEE 802.15.4 berfokus pada spesifikasi dari dua lapisan bawah protocol (lapisan fisik dan lapisan MAC). Di sisi lain ZigBee Alliance bertujuan memberikan lapisanatas dari stack protokol (dari lapisan jaringan kelapisan aplikasi) untuk jaringan data yanginteroperable, menyediakan tes dukungan interoperabilitas, pemasaran teknik, dan standar terkini untuk evolusi standar.

\section{XBee}

XBee merupakan modul yang memungkinkan Arduino untuk berkomunikasi secara wireless menggunakan protokol ZigBee. ZigBee beroperasi pada spesifikasi IEEE802.15.4 radio fisik dan beroperasi pada band berlisensi termasuk $2.4 \mathrm{GHz}, 900 \mathrm{MHz}$ dan $868 \mathrm{MHz}$. Basis XBee berasal dari modul Max Stream. Modul ini memungkinkan komunikasi wireless dalam jangkauan hingga 30 meter (dalam ruangan) atau 100 meter (luarruangan). XBee dapat digunakan sebagai pengganti kabel serial, dapat juga digunakan sebagai mode perintah untuk suatu broadcast, dan pilihan menghubungkan suatu jaringan. Pada dasarnya, XBee merupakan komunikasi serial. Akan tetapi, apabila mode API digunakan, dibutuhkan pemaketan data RF. Untuk itu, data akan di-buffer terlebih dahulu sebelum dikirim atau diterima. Flow data serial menjadi paket RF. Pada XBee apabila ada data input (DI), data akan masuk ke DI buffer. Setelah itu, input data akan diteruskan ke RFTX buffer, kemudian untuk mentransmisikan input data, posisi RF switch menjadi transmitter. Begitu juga sebaliknya, apabila ada data yang diterima, posisi RF switch menjadi 4 receiver lalu data akan masuk RF RX buffer, kemudian data diteruskan ke DO buffer lalu menjadi data output (DO), kemudian DO diteruskan dari XBee ke host. 


\section{$\mathrm{X}-\mathrm{CTU}$}

$\mathrm{X}$-CTU merupakan perangkat lunak yang digunakan untuk mengonfigurasi dan menguji radio modem Max Stream. Pemberian alamat pada XBee dilakukan melalui X-CTU. X-CTU juga dapat mengkonfigurasi XBee menjadi coordinator ataupun menjadi end device. Selain itu, pengaturan retries pada XBee juga dapat dilakukan. X-CTU mendukung XBee Series 1 maupun XBee Pro.

\section{Relay}

Relay adalah saklar yang dikendalikan secara elektronik (electronically switch). Arus listrik yang mengalir pada kumparan relay akan menciptakan medan magnet yang kemudian akan menarik lengan relay dan mengubah posisi saklar, yang sebelumnya terbuka menjadi tertutup atau terhubung. Relay memiliki 2 jenis kutub:

- COMMON (Kutub Acuan).

NC (Normally Close) Kutub yang dalam keadaan awalnya terhubung pada COMMON.

- NO (Normally Open) Kutub yang pada awalnya terbuka dan akan terhubung dengan COMMON saat kumparan relay diberi arus listrik.

\section{Sensor LDR}

Sensor Cahaya LDR (Light Dependent Resistor) adalah salah satu jenis resistor yang dapat mengalami perubahan resistansinya apabila mengalami perubahan penerimaan cahaya. Besarnya nilai hambatan pada Sensor Cahaya LDR (Light Dependent Resistor) tergantung pada besar kecilnya cahaya yang diterima oleh LDR itu sendiri.LDR sering disebut dengan alat atau sensor yang berupa resistor yang peka terhadap cahaya. Biasanya LDR terbuat dari cadmium sulfida yaitu merupakan bahan semikonduktor yang resistansnya berubah-ubah menurut banyaknya cahaya (sinar) yang mengenainya. Resistansi LDR pada tempat yang gelap biasanya mencapai sekitar $10 \mathrm{M} \Omega$, dan ditempat terang LDR mempunyai resistansi yang turun menjadi sekitar $150 \Omega$.

\section{PERENCANAAN SISTEM}

\section{Perancangan Rangkaian Sistem Kontrol dan Monitoring}

Pada perancangan sistem ini menggunakan berbagai aplikasi yang saling berhubungan satu sama lain, dengan mikrokontroler Arduino UNO sebagai pengatur dan pengendali seluruh perangkat pada system kontrol dan monitoring. Seluruh perangkat pada sistem aplikasi kontrol dan monitoring tersebut terintegrasi dengan komputer sebagai pusat kontrol yang dihubungkan melalui interface wireless Xbee, komunikasi antara komputer dan mikrokontroler tersebut dengan menggunakan data serial. Prinsip kerja dari sistem aplikasi ini digunakan sebagai security, monitoring, controlling and automation pada masing-masing ruang perkuliahan didalam kampus. Monitoring tersebut dilakukan oleh sensor yang diaktifkan pada saat program aplikasi dijalankan. Pada proses pengontrolan dilakukan oleh komputer, sistem kerja alat tersebut dapat dilihat pada blok diagram dibawah ini:

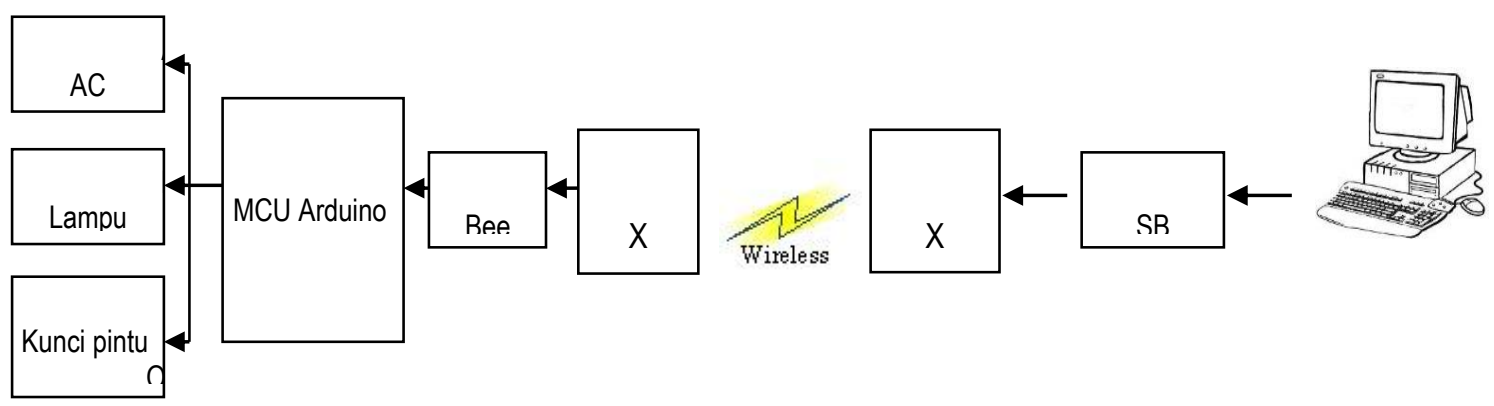

GAMBAR 1. Blok diagram aplikasi sistem kontrol dan monitoring.

Cara kerja dari blok diagram diatas adalah komputer yang digunakan sebagai server, setelah kita membuka dan menjalankan aplikasi kontrol dan monitoring pada komputer server, lalu petugas akan memberikan perintah atau mengaktifkan peralatan listrik pada ruangan kelas yang telah 
ditentukan. Selanjutnya perintah tersebut akan dikirimkan melalui Board USB Adapter Xbee yang sudah interface dengan modul ZigBee TX, data tersebut lalu dimodulasikan dan dipancarkanke ZigBee RX. Pada ZigBee RX data tersebut di demodulasi yang selanjutnya dibaca oleh Xbee Shiel yang sudah interface terhadap modul Arduino Uno, selanjutnya Arduino akan membaca data informasi tersebut, dan selanjutnya memberikan perintah logika "A" pada IC ULN 2003 yang selanjutnya mengaktifkan relay 1 yang artinya lampu menyala, begitu juga bila ingin menyalakan peralatan listrik yang lainnya. Komunikasi ini adalah komunikasi dua arah menggunakan data serial, dengan menggunakan ZigBee. Dengan dihubungkannya Xbee Coordinatoor dan Xbee Router, maka router dapat melakukan pengiriman data informasi langsung secara otomatis kepada petugas kontrol. Seluruh kegiatan sistem dikontrol dan dimonitoring secara keseluruhan oleh petugas kontrol.

\section{Perancangan Tampilan Antarmuka Perangkat Lunak}

Salah satu komponen penting dalam pembuatan program adalah tampilan antarmuka (interface) program tersebut. Selain aliran (root) dari program yang menentukan sebuah program mudah dioperasikan atau tidak, tampilan antarmuka (interface) juga berpengaruh dalam hal tersebut. Seseorang akan senang mengoperasikan program komputer apabila orang tersebut menyukai tampilan dari program komputer tersebut. Apabila interface dan screen tidak efisien dan membingungkan bagi pengguna, orang akan kesulitan melakukan pekerjaannya dan akan membuat banyak kesalahan. Desain yang buruk akan membuat pengguna malas mengoperasikannya. Selain itu juga menyebabkan terjadinya frustasi dan stress. Desain interface yang buruk juga berpengaruh pada keuangan pada pengguna dan organisasi. Perancangan pada dasarnya meliputi: Tampilan Awal, Login, Tampilan Menu, dan Ruangan Kelas. Setelah menjalan aplikasi tersebutakan keluar form tampilan awal, setelahs elesai loading akan masuk ke form selanjutnya yaitu form login. Di form ini user atau pengguna diwajibkan memasukkan User Name dan Password lalu klik tombol OK, setelah berhasil masuk selanjutnya akan tampil Form Menu, dimana user atau pengguna bisa memilih ruangan kelas yang ingin diaktifkan atau dinyalakan peralatan listriknya. Cara menjalankan program AplikasiSistem Monitoring RuanganKelasakan dijelaskan lebih lengkap pada Lampiran.

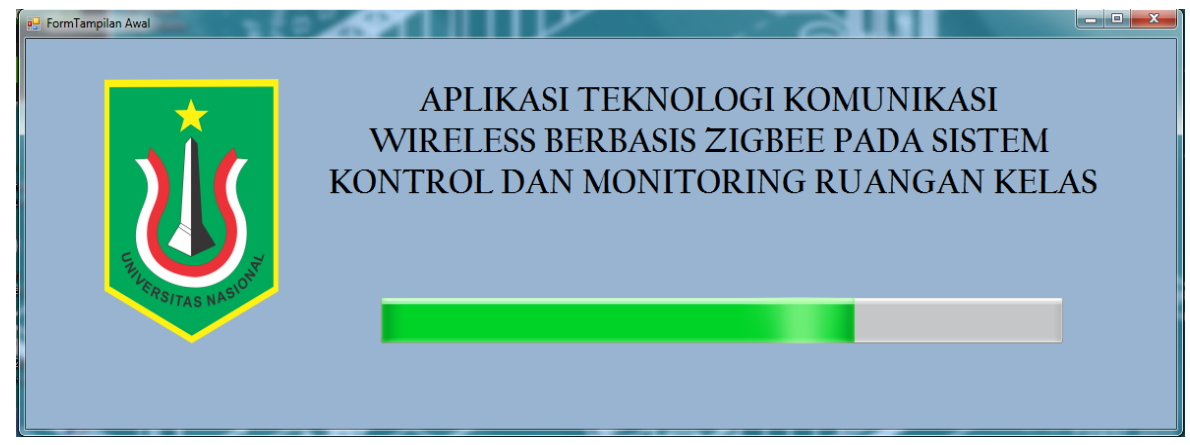

GAMBAR 2. Tampilan Form awal.

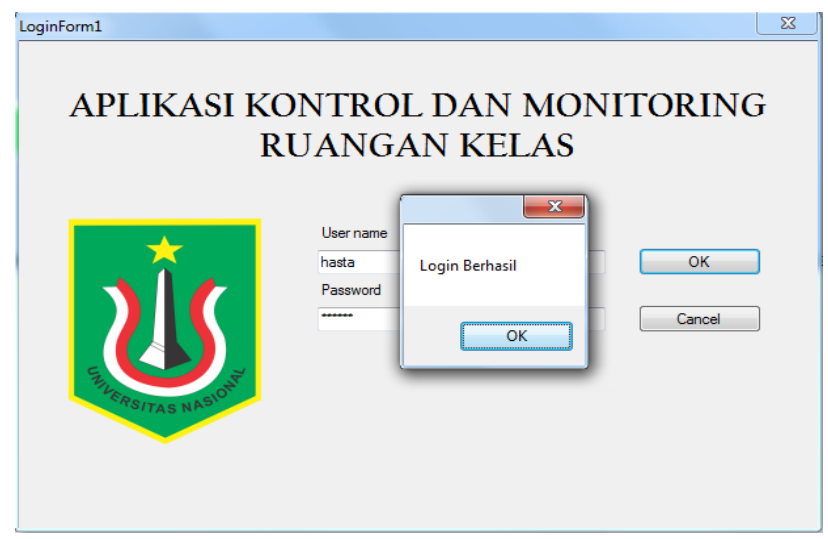

GAMBAR 3. Tampilan Form Login 


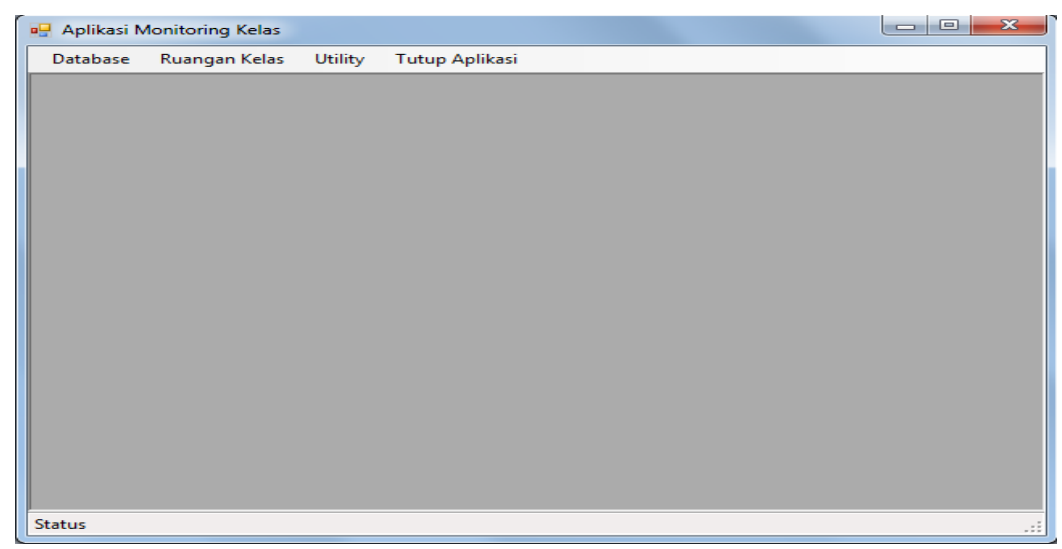

GAMBAR 4. Tampilan Form Menu
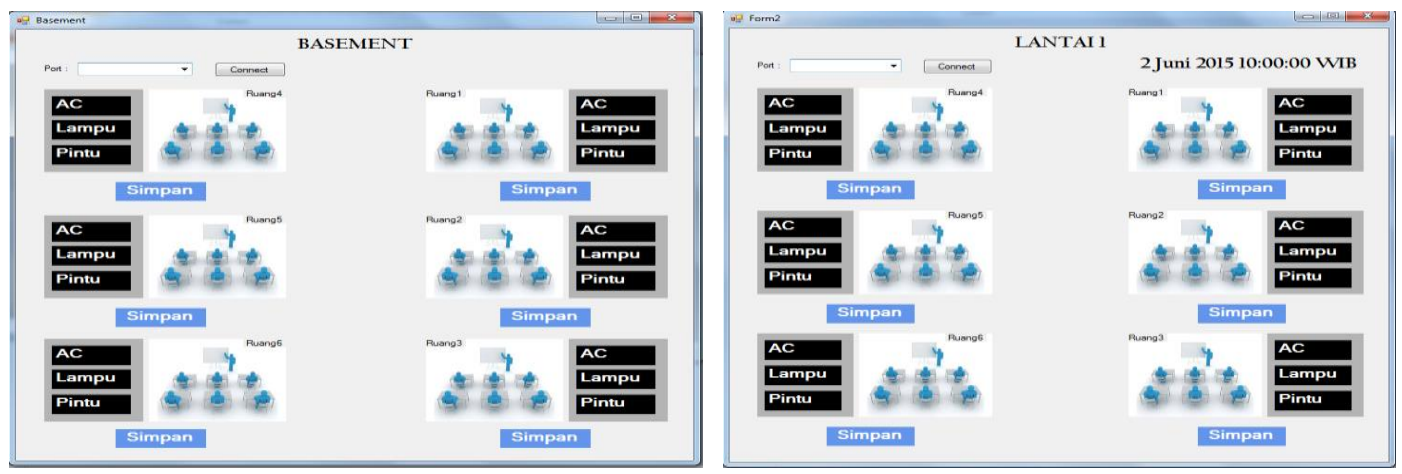

GAMBAR 5. Tampilan Form Lantai

\section{USB Adaptor XBee}

Pada bagian ground segment XBee yang digunakan ditambahkan XBee USB Adapter agar dapat langsung terhubung dengan PC/laptop dan mengeluarkan data serial yang dikirimkanpada RX XBee.
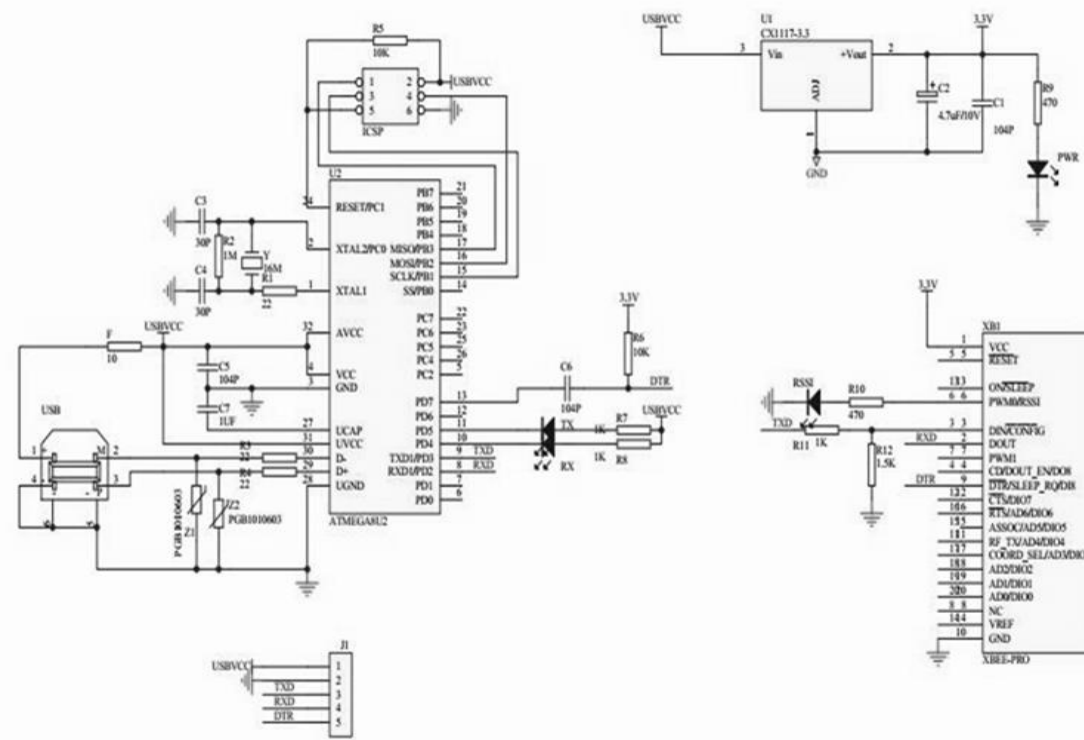

GAMBAR 6. Xbee USB adapter schematic.

\section{Xbee Shield}

Xbee Shield merupakan modul tambahan yang dipergunakan untuk menghubungkan antara board Arduino Uno dengan XBee S2 yang digunakan Xbee Shield ini memungkinkan board 
Arduino Uno untuk berkomunikasi secara wireless menggunakan XBee S2 dengan dilengkapi LED indikasi RSSI.

\section{Rangkaian LDR (Light Dependen Resistor)}

Prinsip kerja LDR itu sendiri adalah dipengaruhi cahaya, yaitu nilair esistansinya akanbertambah besar apabila tidak terkena cahaya (gelap) dan akan mengecil resistansinya apabila terkena cahaya (terang), dalam rangkaian ini kerja LDR resistanssinya akan berubah seiring dengan perubahan intensitas cahaya yang mengenainya. Pada pengujian ini program LDR memakai pin A1 pada Arduino Mega328.

\section{Perancangan Rangkaian Driver Relay}

Rangkaian driver relay adalah rangkaian yang digunakan sebagai saklar untuk mengontrol peralatan listrik ruangan kelas. Pada perancangan ini, beban yang harus dikontrol adalah lampu dan AC yang memiliki tegangan 220 volt. Untuk menyalakan dibutuhkan relay, yang mana dibutuhkan driver relay untuk menggerakkannya.

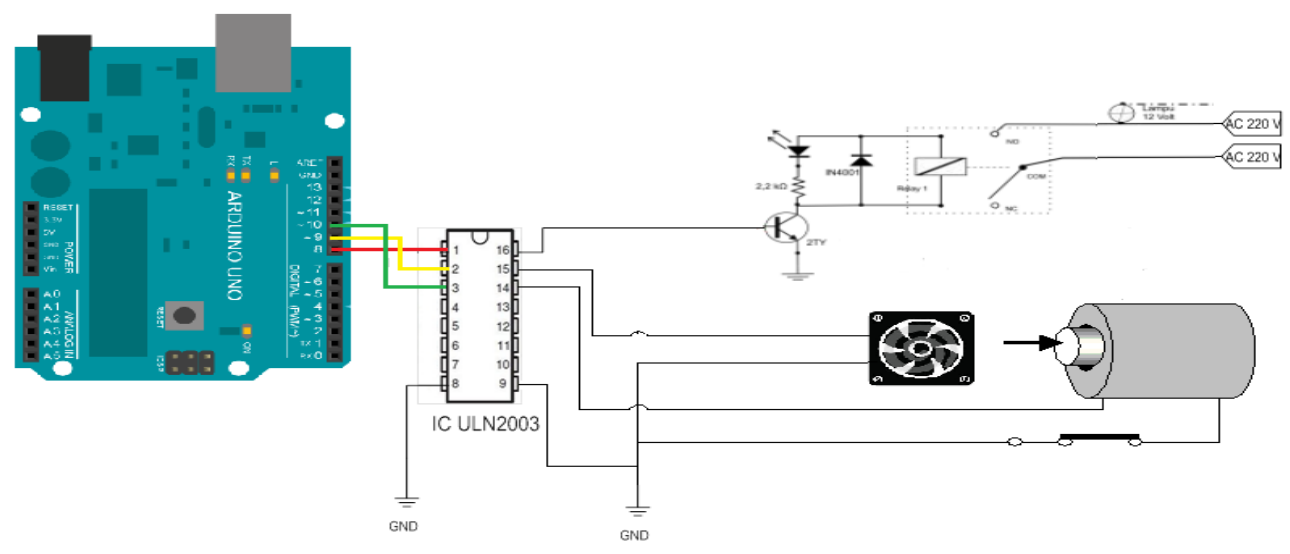

GAMBAR 7. Tampilan diver relay, fan dan solenoid.

Driver bertipe active high atau kumparan relay akan aktif saat pin pengendali diberilogika "1" dari mikrokontroler.

\section{Perancangan Software Aplikasi Sistem Kontrol dan Monitoring}

Prinsip kerja pada software aplikasi ini adalah untuk melakukan pengontrolan, maupun pemonitoring-an secara menyeluruh. Petugas kontrol dapat me-remote komputer server dengan client. Setelah selesai melakukan proses login maka software akan melakukan interkoneksi keaplikasi system untuk mengaktifkan. Selain melakukan pengaktifan, program juga melakukanp embacaan data melalui serial port. Apabila terjadi keadaan yang diinginkan pada ruangan kelas maka mikrokontroler akan mengirimkan data ke program aplikasi, dan program aplikasi akan menunjukakan kondisi peralatan listrik ruangan kelas yang bermasalah. Pada proses pengontrolan pada ruangan kelas, program aplikasi akan memberikan perintah kepada mikrokontroler dengan mengirim data serial. Data tersebut akan dibaca mikrokontroler untuk segera melakukan tindakan. Apabila program tidak menerima data apapun dari mikrokontroler maka kondisi ruangan kelas dalam keadaan normal.

\section{PENGUJIAN SISTEM}

Pengujian sistem dilakukan dengan mengujip erangkat keras dan perangkat lunak dari sistem secara keseluruhan yang telah selesai dibuat untuk mengetahui komponen-komponen sistem apakah berjalans esuai dengan perancangan atau tidak.

\section{Pengujian Mikrokontroler Arduino}

Pengujian mikrokontroler arduino dilakukan untuk mengetahui apakah mikrokontrole rtersebut dapat berjalan dengan baik ataut idak. Pengujian arduino dilakukan dengan menulis progran dan melakukan upload ke arduino berjalan dengan baik. 


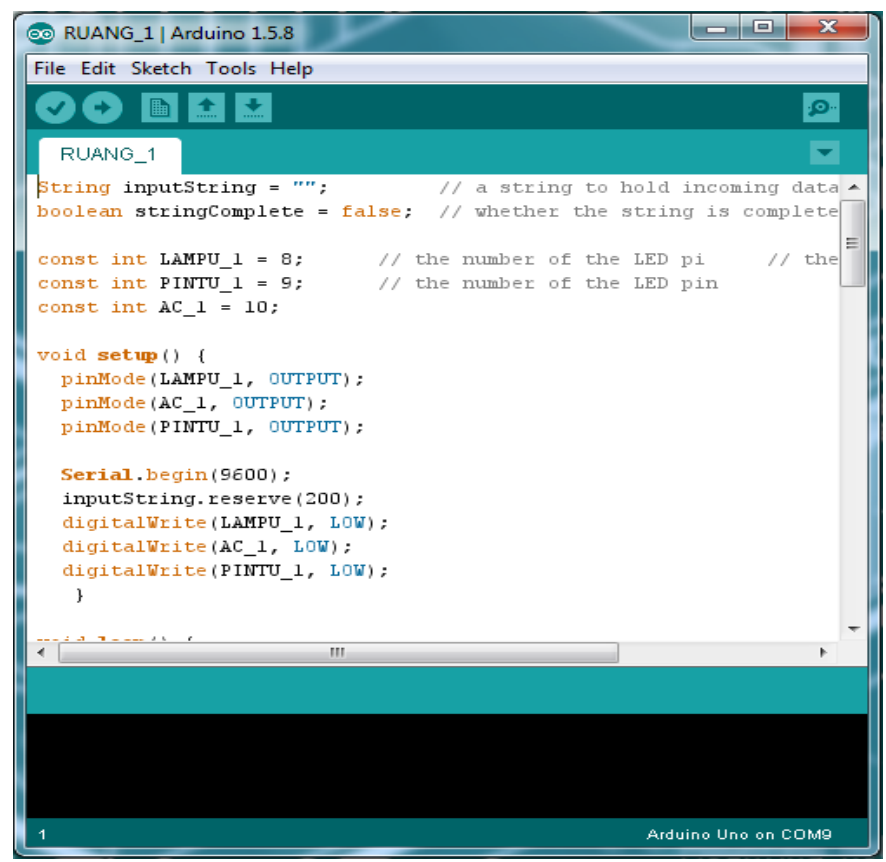

GAMBAR 8. Pengujian terhadap arduino.

\section{Pengujian Xbee}

Pengujian komunikasi Xbee ini dilakukan untuk mengetahui kamunikasi antar Xbee koordinator dengan Xbee router. Pengujian komunikasi Xbee ini dilakukan dengan mengkonfigurasi parameter yang telah dilakukan dengan baik dan dapat diterima serta ditampilkan pada layar komputer.

\section{Hasil pengujian}

Dari prosedur pengujian komunikasi data antar Xbee yang telah dilakukan dapat berjalan dengan baik, pada Gambar dibawah adalah hasil pengujian komunikasi antar xbee.

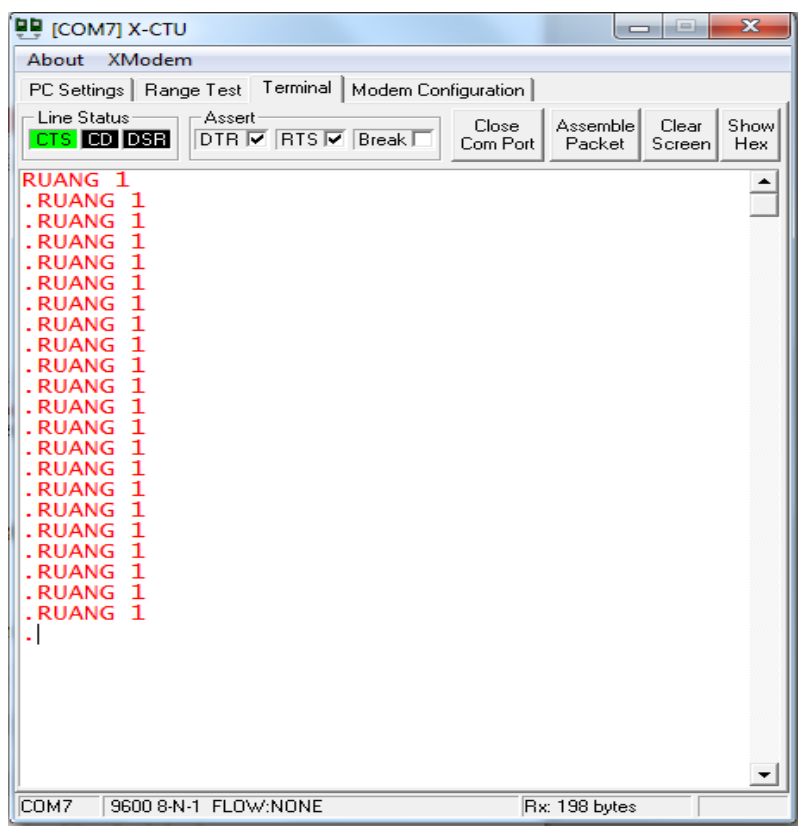

GAMBAR 9. Hasil pengujian komunikasi antar xbee.

Pengujian jarak makimal kemampuan pengiriman data Xbee S2

Untuk mengetahui kemampuan jangkauan area Xbee S2 dalam melakukan penerimaan data dari 
Xbee S2. Dari prosedur pengujian komunikasi data pada Xbee yang telah dilakukan di luar ruangan (Outdoor Area) didapatkan hasil pengamatan jangkauan sebagai berikut : Tabel Hasil Pengamatan Jangkauan Xbee Dalam Kondisi Di Luar Ruangan (Outdoor Area)

TABEL 1. Beberapa hasil pengujian Xbee.

\begin{tabular}{|c|c|c|}
\hline No. & Jarak (Meter) & Keterangan \\
\hline 1 & 5 & Aktif \\
\hline 2 & 10 & Aktif \\
\hline 3 & 15 & Aktif \\
\hline 4 & 20 & Aktif \\
\hline 5 & 25 & Aktif \\
\hline 6 & 30 & Aktif \\
\hline 7 & 35 & Aktif \\
\hline 8 & 40 & Aktif \\
\hline 9 & 45 & Aktif \\
\hline 10 & 50 & Aktif \\
\hline 11 & 55 & Aktif \\
\hline 12 & 60 & Aktif \\
\hline 13 & 65 & TidakAktif \\
\hline
\end{tabular}

Dik : TX $=20 \mathrm{dBm} ; \mathrm{RX}=(-96) \mathrm{dBm} ; \mathrm{F}=2,4 \mathrm{GHz} ; \mathrm{D}=60$ meter

$\mathrm{RSL}(\mathrm{RX})=\mathrm{TX}-\mathrm{FSL}$

RSL $(\mathrm{RX})=20-32,44+20 \log 2400+20 \log 0,06$

$\mathrm{RSL}(\mathrm{RX})=20-92,44+67,60+(-24,4)$

$\mathrm{RSL}(\mathrm{RX})=20-75,64$

RSL (RX) $=-55,64 \mathrm{dBm}$

Jika pada pada jarak 65 meter maka nilai dari RSL (RX) :

$\mathrm{RSL}(\mathrm{RX})=\mathrm{TX}-\mathrm{FSL}$

$\mathrm{RSL}(\mathrm{RX})=20-32,44+20 \log 2400+20 \log 0,065$

$\mathrm{RSL}(\mathrm{RX})=20-32,44+67,60+(-23,74)$

$\operatorname{RSL}(\mathrm{RX})=20-76,3$

$\operatorname{RSL}(\mathrm{RX})=-56,3 \mathrm{dBm}$

\section{Pengujian Komunikasi XBee S2}

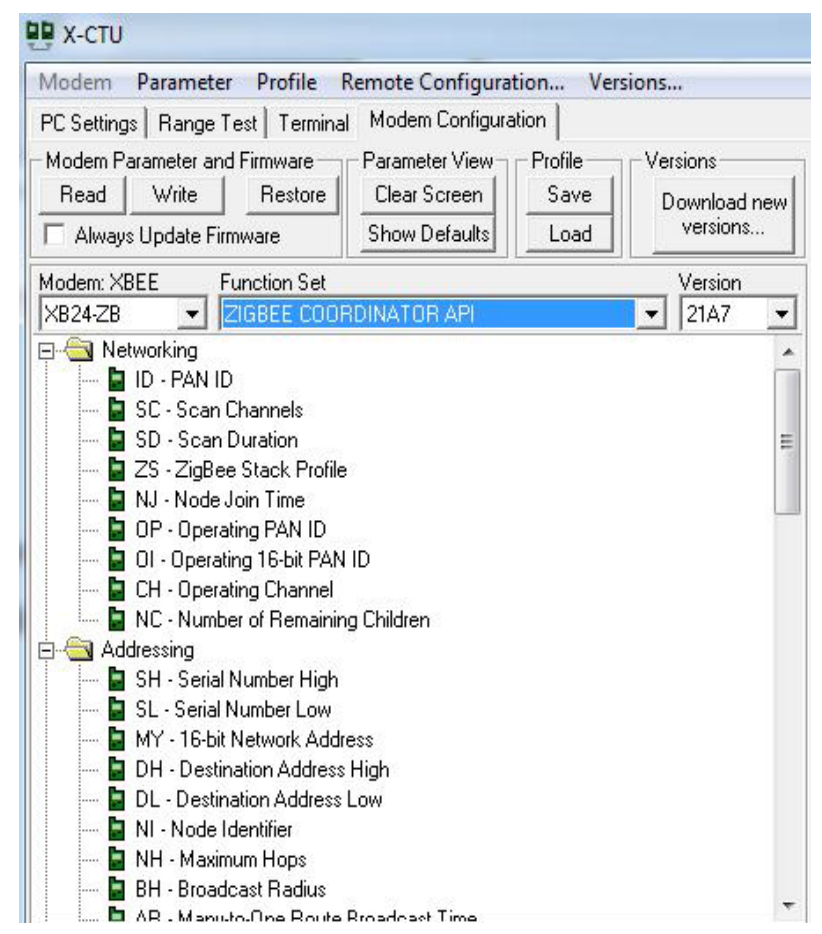

GAMBAR 10. Konfigurasi XBee S2 sebagai coordinator 
Pengujian komunikasi XBee S2 dilakukan dengan menguji komunikasi antardua XBee S2 (topologi peer to peer), kemudian menguji komunikasi dengan tiga XBee S2 sebagai pengirim dan satu XBee S2 sebagai penerima (topologi star) dan yang terakhir menguji dengan topologi mesh. Sebelum melakukan pengujian komunikasi, maka telemetri XBee S2 harus dikonfigurasi terlebih dahulu. Konfigurasi untuk telemetri XBee S2 yang digunakan dalam penelitian ini ada tiga jenis yaitu konfigurasi coordinator, route dan end device dengan menggunakan perangkat lunak X-CTU. Untuk konfigurasi coordinator dapat dilihatp ada gambar 10.

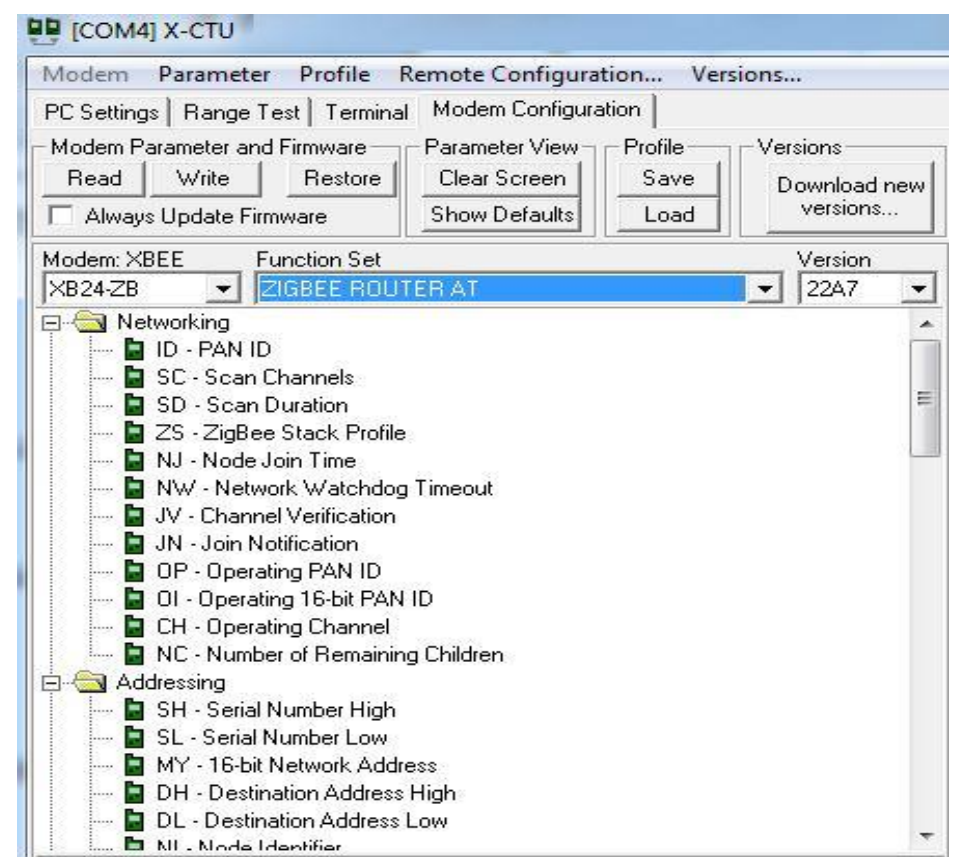

GAMBAR 11. Konfigurasi XBee S2 sebagai router

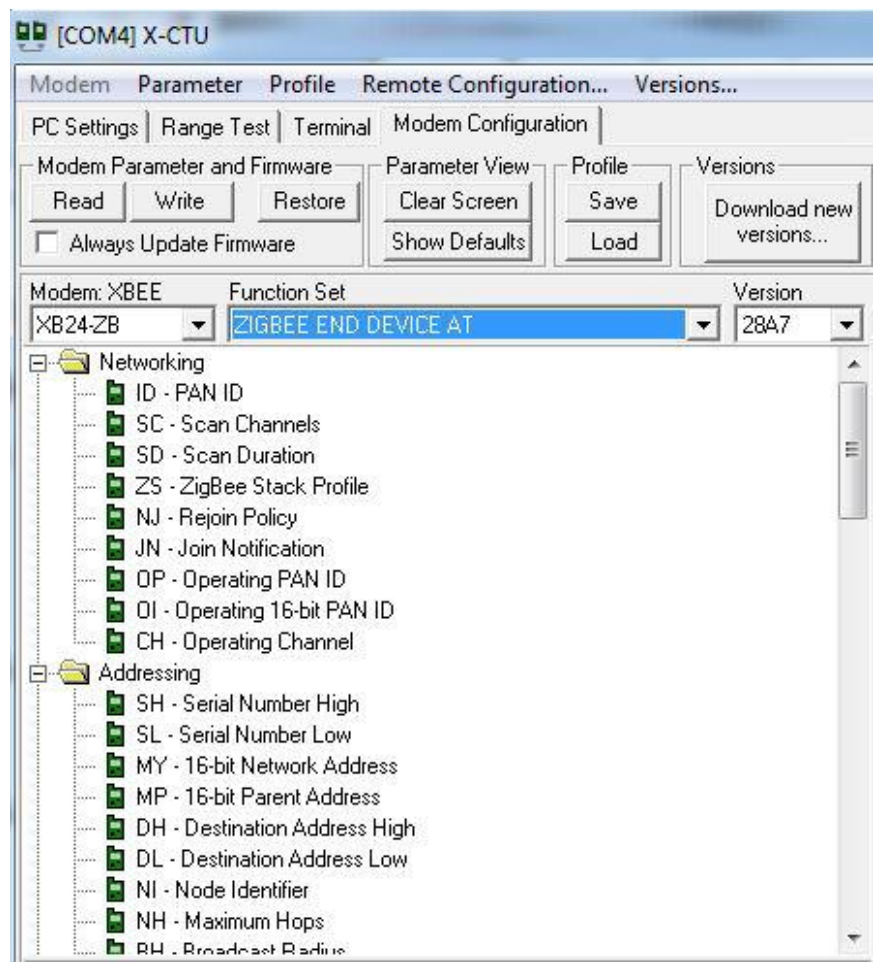

GAMBAR 12. Konfigurasi XBee $\mathrm{S} 2$ sebagai end device 


\section{Pengujian Perlengkapan Listrik Ruangan Kelas}

Pengujian perlengkapan listrikr uangan kelas dilakukan untuk mengetahui kondisi perlengkapan listrik dalam keadaan ON dan OFF.

TABEL 2. Pengujian perlengkapan listrik ruangan kelas.

\begin{tabular}{|c|l|l|l|c|c|}
\hline \multicolumn{2}{|c|}{ AC } & \multicolumn{2}{c|}{ LAMPU } & \multicolumn{2}{c|}{ PINTU } \\
\hline ON & \multicolumn{1}{c|}{ OFF } & \multicolumn{1}{c|}{ ON } & OFF & ON & OFF \\
\hline BERHASIL & BERHASIL & BERHASIL & BERHASIL & BERHASIL & BERHASIL \\
\hline BERHASIL & BERHASIL & BERHASIL & BERHASIL & BERHASIL & BERHASIL \\
\hline BERHASIL & BERHASIL & BERHASIL & BERHASIL & BERHASIL & BERHASIL \\
\hline BERHASIL & BERHASIL & BERHASIL & BERHASIL & BERHASIL & BERHASIL \\
\hline BERHASIL & BERHASIL & BERHASIL & BERHASIL & BERHASIL & BERHASIL \\
\hline BERHASIL & BERHASIL & BERHASIL & BERHASIL & BERHASIL & BERHASIL \\
\hline BERHASIL & BERHASIL & BERHASIL & BERHASIL & BERHASIL & BERHASIL \\
\hline BERHASIL & BERHASIL & BERHASIL & BERHASIL & BERHASIL & BERHASIL \\
\hline BERHASIL & BERHASIL & BERHASIL & BERHASIL & BERHASIL & BERHASIL \\
\hline BERHASIL & BERHASIL & BERHASIL & BERHASIL & BERHASIL & BERHASIL \\
\hline
\end{tabular}

Pengujian aplikasi dilakukan dengan menggunakan hyperterminal, untuk dapat melihat data kirim maupun data terima melalui komputer. Bentuk data yang digunakan adalah menggunakan data serial. Implementasi antarmuka dilakukan dengan setiap tampilan program yang dibangun. Berikut ini adalah implementasi antarmuka dari perangkat lunak Aplikasi Teknologi Komunikasi Wireless Berbasis ZigBee Pada Sistem Kontrol dan Monitoring Ruangan Kelas. Merupakan tampilan awal dari aplikasi monitoring ruangan kelas

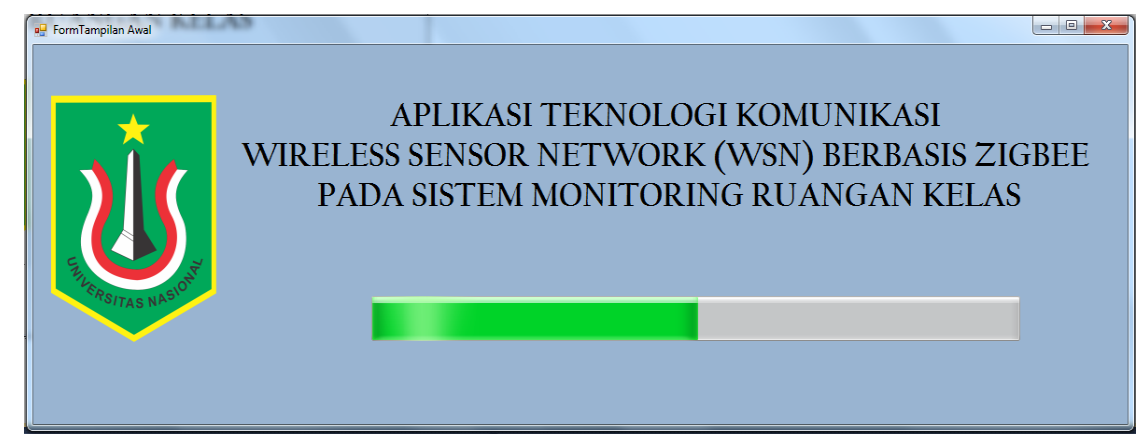

GAMBAR 13. Antarmuka aplikasi monitoring kelas.

Antarmuka pengisian login aplikasi merupakan tampilan login untuk verifikasi data sebelum masuk ke form selanjutnya.

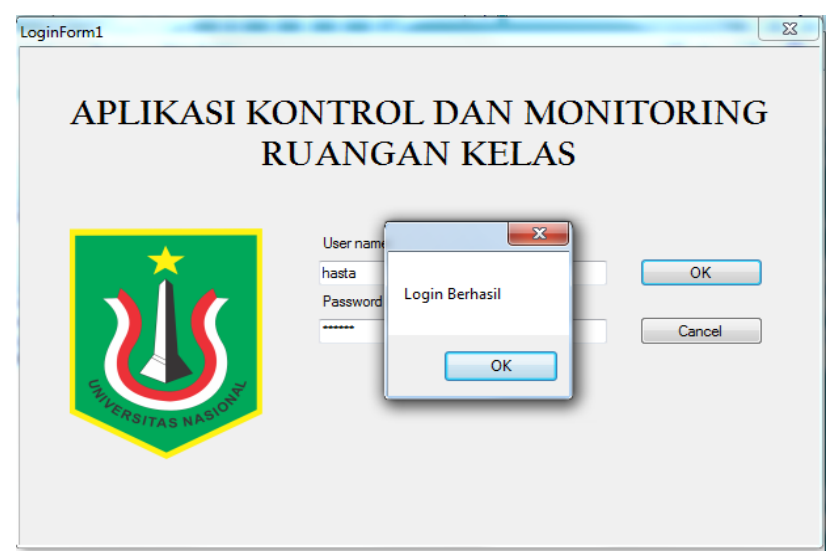

GAMBAR 14. Antarmuka pengisian login aplikasi. 
Antarmuka menu utama merupakan tampilan menu yang tampil setelah login

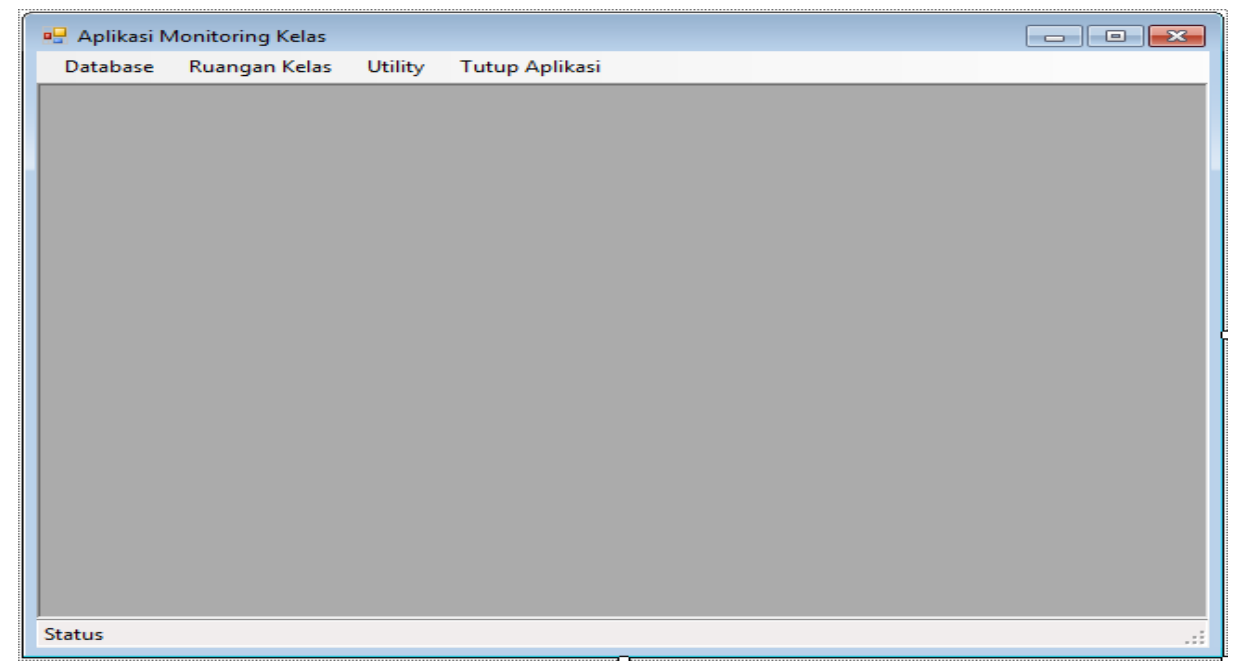

GAMBAR 15. Antarmuka menu utama.

Antarmuka ruangan kelas merupakan tampilan ruangan kelasp ada lantai basement, pada tampilan ini menyatakan ruangan kelas dalam kondisi AC, Lampu, PintuRuangan 1 ON.

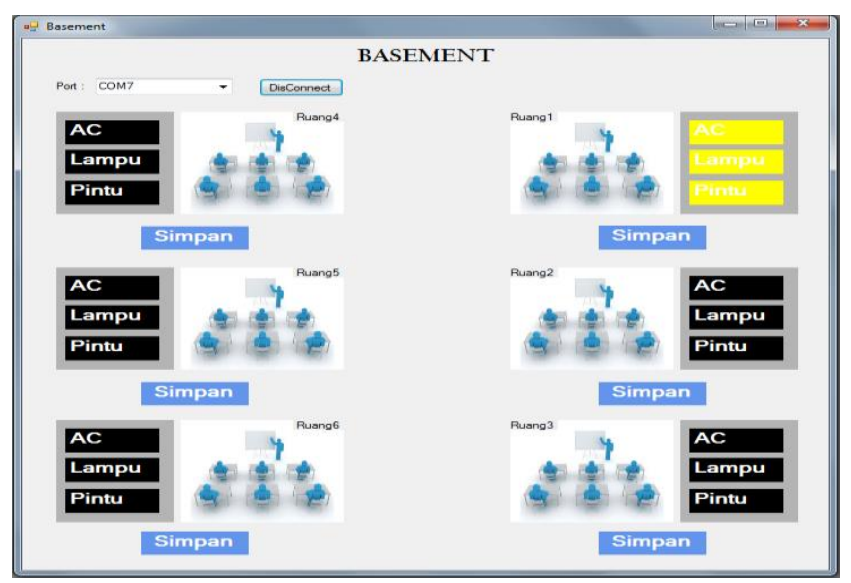

GAMBAR 16. Antarmuka ruangan kelas.

Antarmuka show data basement merupakan tampilan hasil dari hasil record kondisi ruangan kelas ketika ON

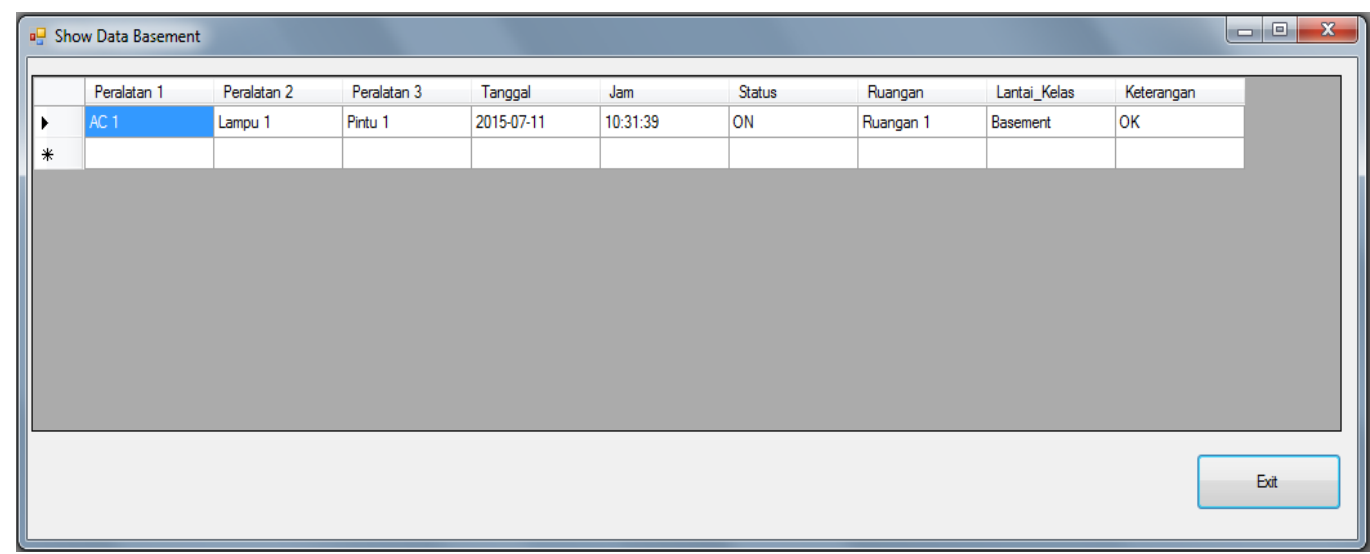

GAMBAR 17. Antarmuka show data basement. 


\section{KESIMPULAN}

Berdasarkan penelitian yang telah dilakukan dapat diambil kesimpulan bahwa telah berhasil dirancang sebuah sistem kontrol dan monitoring secara nirkabel dengan Xbee pada ruangan kelas. Pengujian komunikasi data pada Xbee yang telah dilakukan di luar ruangan (Outdoor Area) didapatkan hasilhanya sampai pada jarak 60 meter. Sedangkan komunikasi antara Arduino UNO dengan Xbee shield dan juga modul Xbee berjalan dengan baik yang difungsikan sebagai kontrol dan monitoring. Sementara jarak dan kecepatan pengiriman data dipengaruhi oleh kekuatan sinyal XBee S2 melalui jaringan nirkabel yang digunakan sebagai media transmisi data.

\section{DAFTAR PUSTAKA}

[1] Nugra, Perkasa, Sistem Kontrol Jarak Jauh Melalui Media Jaringan Komputer Untuk Mengontrol Penerangan Ruangan Dan Air Conditioner (AC) Pada Laboratorium STMIK AMIKOM Yogyakarta Dalam Bentuk Maket Berbasis Mikrokontroler Arduino, Laporan Penelitian Teknik Informatika STMIK AMIKOM, Maret, 2013.

[2] Arduino Uno board, "Based on the ATmega 328 (datasheet)", http://arduino.cc/en/Main/ArduinoBoardUno, 24.09.2013.

[3] Atmel Corporation, "8-bit Microcontroller with 4K Bytes In-System Programmable Flash”, http://www.atmel.com/Images/doc2487.pdf, 2008, 05.11.2013.

[4] M. Ary Heryanto, ST dan Wisnu Adi P, Ir, Pemrograman Bahasa C untuk Mikrokontroler Atmega 328, Yogyakarta, Andi.

[5] "Visual Basic.NET Tutorial" http://mkasoft.com/downloads/VB.NET\%20programming.pdf

[6] Neda Noorani, "Wireless Multi-Sensor Monitoring System Utilizing IEEE 802.15.4 Communication Standards for Water Leakage Detection", Department of Electrical and Computer Engineering

[7] ZigBee Alliance, ZigBee and Wireless Radio Frequency Coexistence, White paper date june 2007. 